\title{
The Relationship among Dissolved Inorganic Phosphate, Particulate Inorganic Phosphate, and Chlorophyll-a in Different Seasons in the Coastal Seas of Semarang and Jepara
}

\author{
Lilik Maslukah ${ }^{1,2^{*}}$, Muhammad Zainuri ${ }^{2}$, Anindya Wirasatriya ${ }^{2,3}$, Siti Maisyarah ${ }^{2}$ \\ 1 Doctoral Program of Marine Science, Faculty of Fisheries and Marine Science, Diponegoro University, \\ Indonesia \\ 2 Department of Oceanography, Faculty of Fisheries and Marine Science, Diponegoro University, Indonesia \\ 3 Center for Coastal Rehabilitation and Mitigation Studies, Diponegoro University, Indonesia \\ * Corresponding author's e-mail: lilik_masluka@yahoo.com
}

\begin{abstract}
The speciation of particulate inorganic phosphate (PIP) in waters is still rarely studied, unlike the dissolved inorganic phosphate (DIP) which is often used in the assessment of the water quality parameters and their effect on the presence of chlorophyll a. This research aimed at determinig the relationship between DIP and PIP and its effect on the concentration of chlorophyll-a. This research was conducted in the waters of Semarang and Jepara, in different seasons (Rainy and dry). Speciation from PIP was obtained through an extraction process using $1 \mathrm{M} \mathrm{HCL}$ and continued with phosphate analysis using the molybdenum blue method, as in the DIP analysis. The linear model was used to find an equation and determine the variables that affect chlorophyll a. Our results showed that the distribution patterns of DIP, PIP and Chlorophyll-a have different patterns in the two study areas and different seasons. The concentration of DIP is always high in the Semarang waters, and is followed by a high chlorophyll-a response. A different pattern was found in the Jepara waters, where the chlorophyll-a response is high in the east monsoon. The relationship of Chl-a to DIP was very significant in the west season in the waters of Semarang and the Jepara region in the east season $(p<0.05)$. The relationship of chlorophyll a to DIP in the Semarang and Jepara waters produced an equation, $\mathrm{Chl} \mathrm{a}=-56.565+76.672$ (DIP) with a coefficient of determination $\mathrm{R}^{2}=0.478$, at a significant level $(\mathrm{p})=0.004$ and $\mathrm{Chl} \mathrm{a}=-25.844+68.827$ (DIP) with value of $\mathrm{R}^{2}=0.421$ at a significance level of $\mathrm{p}=0.007$, respectively.
\end{abstract}

Keywords: dissolved, particulate, inorganic phosphate, Semarang, Jepara

\section{INTRODUCTION}

The high level of human activity has had a significant effect on the increase of the pollutant input into estuarine waters (William et al. 2010). This region covers $7 \%$ of the world's surface area and has $30 \%$ of the total net primary production (Durr et al. 2011). This area is the most active biogeochemical process and is more susceptible to the effects of human activity, especially the tropics (Yule et al. 2010, Smith et al. 2012) and can cause eutrophication (Davidson et al. 2014). Now that the water quality control in aquatic environments in many countries or regions is increasing, it is important to understand the global functional relationship between the phytoplankton biomass, phosphorus and nitrogen in the aquatic ecosystems.

Chlorophyll-a (hereinafter Chl-a) is the most widely used measure of the phytoplankton biomass in the aquatic environments, both lakes or coastal (Balali et al. 2013). Chlorophyll is a useful and easily-employed estimator of phytoplankton standing crop and is now more generally used than the cell number or cell volume (Sakamoto 1966). The relationship between Chl-a and nutrient in water bodies has been intensively studied (Søndergaard et al. 2011; Balali et al. 2013). The concentrations of phosphorus (P) and nitrogen (N) nutrients, together or in isolation, affect the 
concentration of Chl-a (Trommer et al. 2013; Magumba et al. 2013). The relationship of variation is influenced by the factors of latitude, altitude, depth and stoichiometric characteristics (Abell et al. 2012). Maslukah et al. (2018) explained that chlorophyll a in Jepara waters had the strongest correlation to the $\mathrm{N} / \mathrm{P}$ ratio, followed by $\mathrm{P}$ and finally $\mathrm{N}$ individually. The following study, Maslukah et al. (2019), found a relationship of chlorophyll a to nutrient $\mathrm{P}$ following a logarithmic model with the formula $[\mathrm{Chl}-\mathrm{a}]=1.52+1.60 \operatorname{logs}[\mathrm{P}]$, with a correlation coefficient (r) of 0.74 . A comprehensive model of this relationship that can be applied to waters with different characteristics would be very valuable to develop effective policies to control the water quality (Abell et al. 2012).

Phosphorus $(\mathrm{P})$ has generally been considered a limiting nutrient for phytoplankton growth, and excessive $\mathrm{P}$ concentration is considered the most common cause of eutrophication in lakes, rivers, and estuaries (Correll 1998; Al-Enezi et al. 2016; Soliman et al. 2017). Phosphorus in seawater exists in both particulates and dissolved, each containing the organic and inorganic form. The total dissolved P (TDP) is usually defined as a fraction that passes through $0.1-1 \mu \mathrm{m}$ porous filter, which exists in organic and inorganic forms. Dissolved Inorganic Particulate form (DIP) is the dominant fraction. Likewise, the total particulate P (TPP) is in the form of inorganic and organic P (PIP). The inorganic particulates occur in the mineral phase, adsorbed for particles (biotic and abiotic), whereas POP consists of P incorporated in life and detrital organic molecules. The information about the concentration and dynamics of each group are needed to characterize the phosphorus cycle.

The most important bioavailable $\mathrm{P}$ in water is in dissolved form, but its existence is only a small part of the total $\mathrm{P}$ (phosphate) - particulates. Dissolved inorganic phosphate (DIP) are ions that are very easily absorbed by particulates. The estuary sediments can act as sources of $\mathrm{PO}_{4}{ }^{2-}$ (DIP) through the release of suspended substances and inorganic phosphorus sediment particles (PIP) (Froelich, 1988; Al-Enezi, et al., 2016). The $P$ particulate (PIP) in the aquatic environment is an important factor in determining its concentration and availability in water. This form is responsible for the presence of dissolved inorganic phosphate (DIP) in the water column through physical adsorption, chemical bonds or biological assimilation. Thus, the speciation $\mathrm{P}$ study is very interesting (Soliman et al. 2017).
The main $\mathrm{P}$ source, reaching more than 90\% of the total phosphorus, is transported from the run-off rivers to the coastal waters in the form of suspended particulate matter.

The waters on the north coast of Central Java are greatly influenced by the flow of freshwater from large rivers. The upstream river activity has significantly affected the input of suspended material and nutrients to the waters. This region has experienced very rapid development because it is the main center of economic growth in Central Java. Several studies related to the chlorophyll a concentration have been carried out by Siregar and Koropitan (2016), Subiyanto et al. (2017) and Maslukah et al. (2019). The concentration of the particulate $\mathrm{P}$ forms in waters is rarely measured. Considering there is an exchange in DIP and PP, better characterization of the spatial and temporal distribution of various forms of $\mathrm{P}$ is needed to increase our understanding of the $\mathrm{P}$ biogeochemistry.

In this study, the inorganics from particulates (PP) and dissolved $\mathrm{P}$ were measured, which will provide new insights into the spatial and season differences in various $P$ pools as well as their relation to total suspended solids and chlorophyll-a.

\section{MATERIALS AND METHODS}

The research was conducted in the waters of the Semarang and Jepara (Fig. 1) in February (representing the rainy season) and July (representing the dry season) in 2019. The seawater samples were taken at 16 stations (Semarang area) and 15 stations (Jepara area), using Nansen tubes in layers surface $(0.2 \mathrm{D} /$ depth). The water samples were filtered on $0.45 \mathrm{~mm}$ cellulose acetate membranes (millipore) and stored in polypropylene bottles before the measurement of DIP concentrations within $24 \mathrm{~h}$ by means of the molybdate blue method (Murphy and Riley 1962). The chlorophyll a (Chl a) concentrations were determined spectrophotometrically on $90 \%$ acetone extracts of particles from $1000 \mathrm{ml}$ subsamples retained on millipore filters. The supernatant reads its absorbance value at trichromatic wavelengths 664, 645 and 630 (APHA, 1992). The chlorophyll-a concentration is calculated using the formula 1 and 2 (Jeffrey \& Humphrey, 1975):

$$
\begin{gathered}
\mathrm{Ca}=11.85(\lambda 664)-1.54(\lambda 645)-0.008(\lambda 630)(1) \\
\mathrm{Chl}-\mathrm{a}\left(\mathrm{mg} / \mathrm{m}^{3}\right)=\mathrm{Ca} \times v / V
\end{gathered}
$$




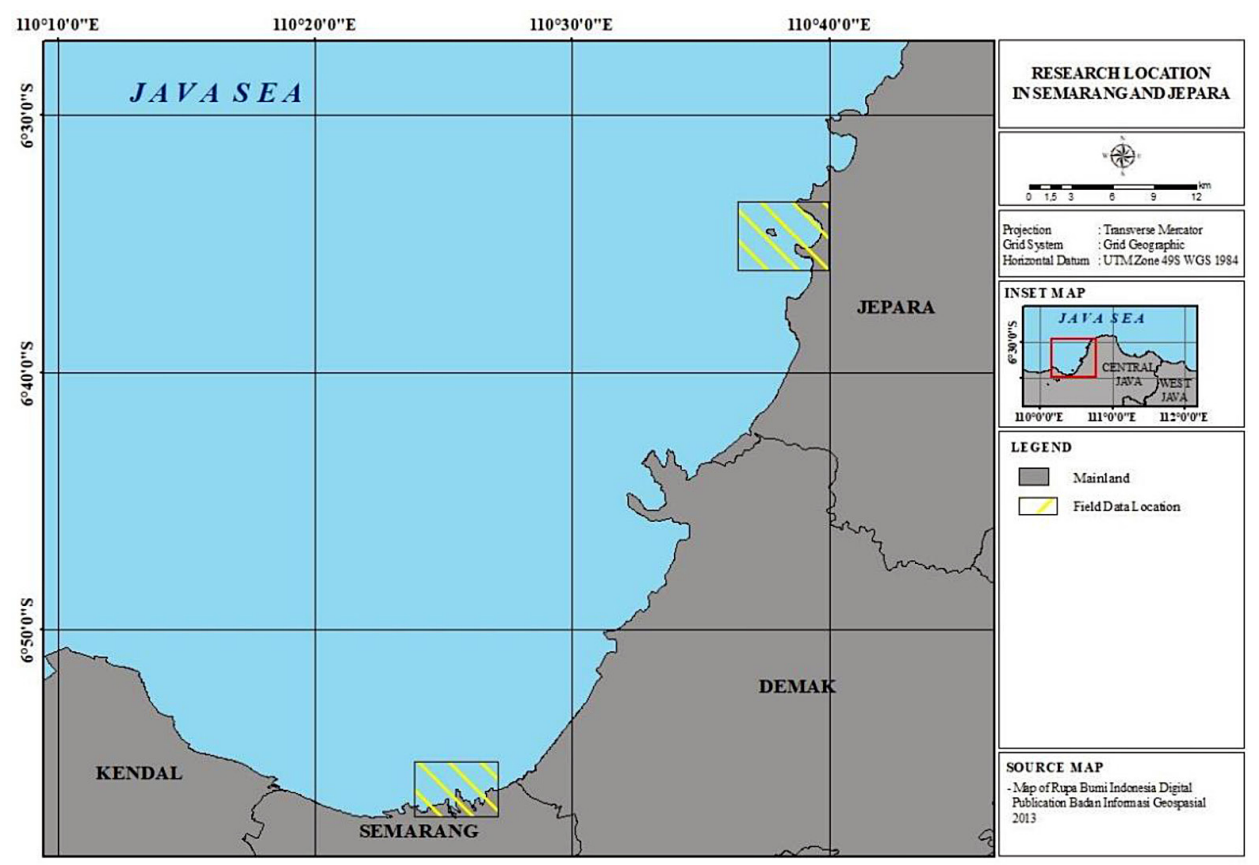

Fig. 1. The map location

where: $\lambda 664, \lambda 645$, and $\lambda 630$ are the reading result of the absorbance value at that wavelength, $v$ - volume extract (liter), $V$ - sample volume $\left(\mathrm{m}^{3}\right)$.

The form of P particulates (PIP) was determined by extracting with $1 \mathrm{M} \mathrm{HCl}$ (Aspila et al. 1976), filtering and supernatant were analyzed using the Molybdenum blue method (Labry et al. 2013). The absorbance value was measured using a Shimadzu UV-VIS Optima spectrophotometer SP 3000, with $1 \mathrm{~cm}$ wide cuvet.

\section{Statistic analysis}

The data were analyzed with the SPSS statistical software v. 16 and Microsoft Office Excel 2007. The normality tests were performed on all data, before further analysis of the regression model. The relationship between variables was carried out using linear regression as well as data correlation and Bivariate tests were performed to find a significant relationship between chlorophyll a to DIP and chlorophyll a.

\section{RESULT AND DISCUSSION}

The study of fractions is essential for better monitoring of the availability of different forms of the $\mathrm{P}$ fraction in the water. The form of the $\mathrm{P}$ species in water bodies studied are dissolved inorganic phosphate (DIP) and particulates inorganic phosphate (PIP). the average concentrations of DIP, PIP, and chlorophyll a from the two study areas are in the range of $0.35-2.53 \mu \mathrm{M}$ (DIP), 1.11-8.32 $\mu \mathrm{M}$ (PIP), 7.2-41.97 $\mathrm{mg} \mathrm{m}^{-3}$ (Chl-a) in the Semarang waters and 0.07-2.09 $\mu \mathrm{M}$ (DIP), 0.18-8.32 $\mu \mathrm{M}$ (PIP), $1.60-12.11 \mathrm{mg} \mathrm{m}^{-3}$ (Chl-a) in the Jepara waters. The concentration of chlorophyll-a in the Semarang waters always shows a higher value (Table 1).

On the basis of Table 1, the concentration of DIP, PIP, TSS, and Chlorophyll-a from two locations and seasons is shown in Figures 2 and 3.

In Figure 2, in the Semarang coastal seas, the concentration of DIP is always higher than in Jepara. However, the chlorophyll-a response shows a different pattern. In the dry season, although the Semarang coastal sea shows higher DIP concentrations, the chlorophyll-a response is more significant in the Jepara waters. Next, the SPM spatial distribution pattern is explained in Figure 3 and illustrates the same pattern as Chl-a. Figure 2 and 3 show that the waters of Semarang in the rainy season always show high values for SPM, DIP, and Chl-a. Conversely, the SPM, DIP and Chl-a concentrations of Jepara coastal waters show higher values in the dry season. This relates to the different hydrodynamic characteristics. In Figure 1, shows the location of these two classes of water in the Java Sea, the Semarang coastal seas are located in a bay and Jepara is in a cape. Wyrtki 
Table 1. The concentration of DIP, PIP, SPM, Chl-a, in Semarang and Jepara coastal seas

\begin{tabular}{|c|c|c|c|c|c|c|c|c|c|}
\hline \multirow{2}{*}{\multicolumn{2}{|c|}{ Season }} & \multicolumn{4}{|c|}{ Semarang } & \multicolumn{4}{|c|}{ Jepara } \\
\hline & & \multirow{2}{*}{$\begin{array}{c}\begin{array}{l}\text { DIP- } \\
(\mu \mathrm{M})\end{array} \\
1.17\end{array}$} & \multirow{2}{*}{$\begin{array}{c}\begin{array}{c}\text { PIP } \\
(\mu \mathrm{M})\end{array} \\
2.31\end{array}$} & \multirow{2}{*}{$\begin{array}{c}\begin{array}{c}\mathrm{SPM} \\
\left(\mathrm{mg} \mathrm{L}^{-1}\right)\end{array} \\
189.00\end{array}$} & \multirow{2}{*}{$\begin{array}{c}\begin{array}{c}\mathrm{Chl} a \\
\left(\mu \mathrm{g} \mathrm{L}^{-1}\right)\end{array} \\
41.97\end{array}$} & \multirow{2}{*}{$\begin{array}{c}\text { DIP } \\
(\mu \mathrm{M})\end{array}$} & \multirow{2}{*}{$\begin{array}{c}\begin{array}{c}\text { PIP } \\
(\mu \mathrm{M})\end{array} \\
5.62\end{array}$} & \multirow{2}{*}{$\begin{array}{c}\begin{array}{c}\text { SPM } \\
\left(\mathrm{mg} \mathrm{L}^{-1}\right)\end{array} \\
72.80\end{array}$} & \multirow{2}{*}{$\begin{array}{c}\begin{array}{c}\text { Chl a } \\
\left(\mu \mathrm{g} \mathrm{L}^{-1}\right)\end{array} \\
12.11\end{array}$} \\
\hline \multirow{4}{*}{$\begin{array}{l}\text { Rainy } \\
\text { season }\end{array}$} & Max & & & & & & & & \\
\hline & Min & 0.87 & 1.11 & 67.00 & 7.07 & 0.07 & 0.50 & 22.40 & 0.91 \\
\hline & Average & 0.97 & 1.61 & 134.27 & 18.06 & 0.50 & 2.68 & 52.76 & 3.95 \\
\hline & STDEV & 0.08 & 0.52 & 43.13 & 8.73 & 0.55 & 2.17 & 16.74 & 3.61 \\
\hline \multirow{4}{*}{$\begin{array}{c}\text { Dry } \\
\text { season }\end{array}$} & Max & 2.53 & 8.32 & 85.00 & 18.35 & 1.11 & 8.32 & 100.00 & 78.82 \\
\hline & Min & 0.35 & 1.43 & 24.00 & 5.72 & 0.38 & 0.18 & 15.40 & 1.60 \\
\hline & Average & 0.76 & 3.87 & 65.75 & 11.41 & 0.59 & 3.53 & 69.15 & 16.05 \\
\hline & STDEV & 0.63 & 2.73 & 15.55 & 3.95 & 0.22 & 3.09 & 23.86 & 23.80 \\
\hline
\end{tabular}

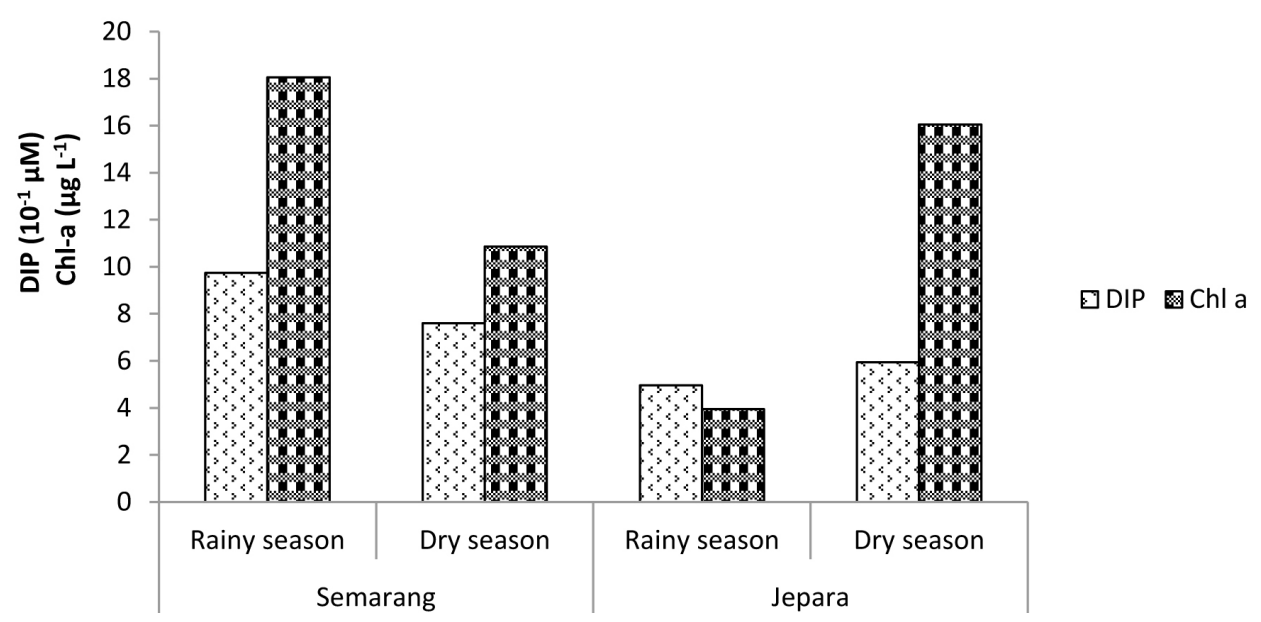

Fig. 2. The concentration of dissolved inorganic phosphate (DIP) and chlorophyll a (Chl-a) in the Semarang and Jepara coastal seas

(1961) explained that the currents occurring in the northern waters of Central Java were the currents generated by the Asian-Australian monsoon system. In the east monsoon (dry season), the direction of the wind moves from east to west and has implications for the direction of the current and movement of the water mass. Shabrina et al. (2018a) explain that the dominant current pattern in the northern waters of Central Java is the component of $u$ (zonal) current in the West-East direction. in the dry season, currents in the Java Sea flow to the west and have caused the measured chlorophyll to be high. This current pattern causes the Jepara waters located in the west of coastal Java to experience the coastal upwelling processes. Wirasatriya et al. (2018) explained that the high Chl-a in the dry season, in the Java Sea waters was due to the mixing process. These characteristics affect the differences in DIP, SPM and chlorophyll-a fluctuation patterns at the two locations. Zhou et al. (2014) explain that Different hydrodynamic processes can regulate the water quality (nutrients, dissolved oxygen, and chlorophyll-a.
The high concentration of DIP in the Semarang waters is due to the influence of larger river flow and has a very high anthropogenic activity compared to the Jepara waters. The results of the study of Maslukah et al. (2018), large river flow has caused quite high nutrient supply to the sea is and resulted in their increased fertility. Compared with the studies on wetlands in Iran (Balali et al. 2013), chlorophyll-a ranged between 4.38 to 156.55 $\mathrm{mg} / \mathrm{m}^{3}$ at a phosphate concentration level of $0.6-22 \mu \mathrm{M}$ in Iran's wetlands.

The PIP distribution pattern differs from DIP, which always shows a high concentration in the rainy season (Figure 4). PIP and DIP in the water column are two forms of phosphate species $\left(\mathrm{PO}_{4}^{2-}\right)$ which are interconnected with one another. The dissolved species can be reduced from water due to the adsorption by suspended solids and the reverse process; the phosphate bound by a suspension can be a source for dissolved species (DIP) (Deborde et al. 2007). 


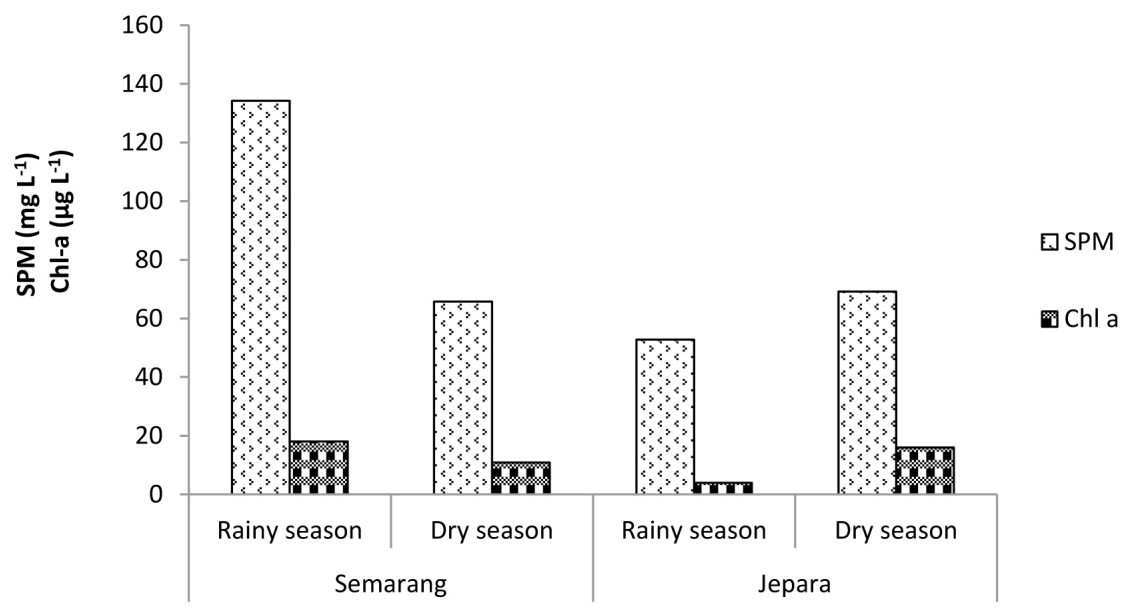

Fig. 3. Distribution of spatial and temporal suspended particulate matter (SPM) and chlorophyll a

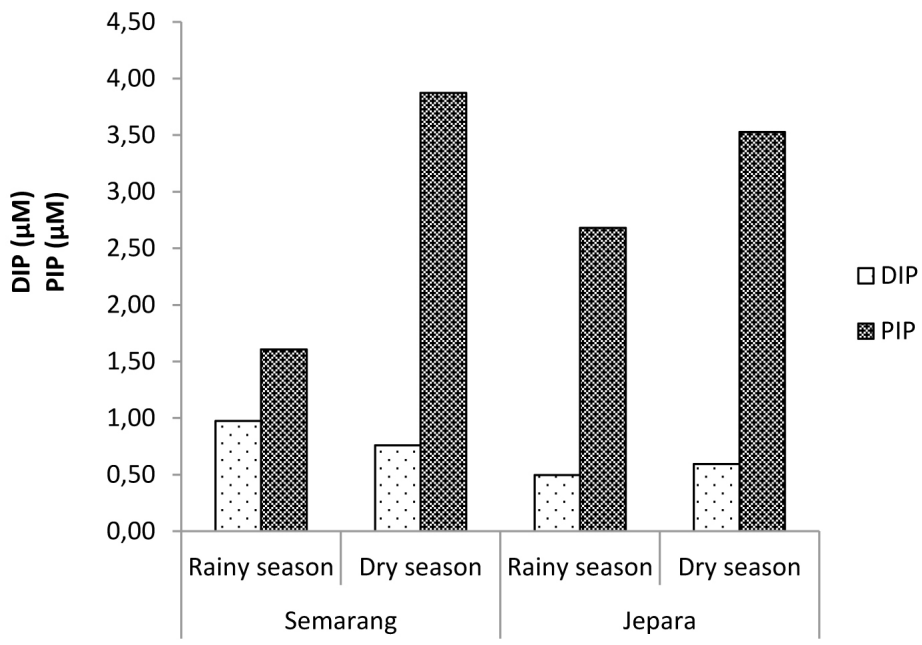

Fig. 4. Distribution of DIP \& PIP in different season in Semarang and Jepara coastal seas

\section{Relationship between DIP, SPM and $\mathrm{Chl}-\mathrm{a}$ and the model equation}

The presence of chlorophyll on the water is largely determined by the concentration of nutrients and suspended particulate matter (SPM). SPM is closely related to the penetration of light and nutrients related to its function in enzymatic reactions. $\mathrm{P}$ (phosphorus) is one of the nutrients that is a biological limiting factor. The DIP concentrations can be used to determine the water fertility. Maslukah et al. (2019) obtained an equation model for the relationship between DIP and chlorophyll-a in Java sea waters, which is $[\mathrm{Chl}-\mathrm{a}]=1.52+1.60 \log [\mathrm{P}]$. This model will vary by location and seasonally. The model of the relationship between chlorophyll a to DIP and SPM at two locations and different seasons have different characteristics (Table 2).

Table 2 explains that the chlorophyll response is simultaneously influenced by DIP and SPM. The Semarang waters show that the chlorophyll response to DIP and SPM is very significant in the rainy season and vice versa, in the Jepara waters

Table 2. Relationship between chlorophyll a, DIP and SPM in the rainy and dry seasons in the Semarang and Jepara coastal seas

\begin{tabular}{|l|l|l|}
\hline \multicolumn{1}{|c|}{ Season } & \multicolumn{1}{|c|}{ Semarang } & \multicolumn{1}{c|}{ Jepara } \\
\hline Rainy season & $\begin{array}{l}\text { Chl } a=78.582(\mathrm{DIP})+0.013(\mathrm{SPM})-60.158 \\
\text { with value } \mathrm{R}^{2}=0.482, \mathrm{p}=0.019, \mathrm{n}=14\end{array}$ & $\begin{array}{l}\text { Chl } \mathrm{a}=1.811(\mathrm{DIP})+0.109(\mathrm{SPM})+0.109 \\
\text { with value } \mathrm{R}^{2}=0.157, \mathrm{p}=0.505, \mathrm{n}=10\end{array}$ \\
\hline Dry season & $\begin{array}{l}\mathrm{Chl} \mathrm{a}=-3.224(\mathrm{DIP})-0.029(\mathrm{SPM})+16.72 \\
\text { with value } \mathrm{R}^{2}=0.354, \mathrm{p}=0.140, \mathrm{n}=11\end{array}$ & $\begin{array}{l}\text { Chl a }=67.782(\mathrm{DIP})-0.257(\mathrm{SPM})-7.481 \\
\text { with value } \mathrm{R}^{2}=0.490, \mathrm{p}=0.013, \mathrm{n}=15\end{array}$ \\
\hline
\end{tabular}

Note: $\mathrm{R}$ - coefficient of determination, $\mathrm{r}$ - coefficient of correlaiton, $\mathrm{n}$ - total data, $\mathrm{p}$ - significance. 
Table 3. The equation model of the relationship Chl a to DIP

\begin{tabular}{|c|c|c|c|}
\hline \multicolumn{2}{|c|}{ Semarang } & \multicolumn{2}{|c|}{ Jepara } \\
\hline Rainy season & Dry season & Rainy season & Dry season \\
\hline $\begin{array}{c}\text { Chl } a=-56.565+76.672(\mathrm{DIP}) \\
\left(\mathrm{R}^{2}=0.478, p=0.004, n=14\right. \\
\& \mathrm{r}=0.692)\end{array}$ & $\begin{array}{c}\text { Chl } a=13.498-2.746(\text { DIP }) \\
\left(R^{2}=0.190, p=0.091, n=14\right. \\
\& r=-0.436)\end{array}$ & $\begin{array}{c}\text { Chl } a=3.928+0.050(\text { DIP }) \\
\left(R^{2}=0.000, p=0.982, n=14\right. \\
\& r=0.008)\end{array}$ & $\begin{array}{c}\text { Chl } a=-25.844+68.827 \text { (DIP) } \\
\left(R^{2}=0.421, p=0.007, n=14\right. \\
\& r=0.649)\end{array}$ \\
\hline
\end{tabular}

Note: $\mathrm{R}$ - coefficient of determination, $\mathrm{r}$ - coefficient of correlaiton, $\mathrm{n}$ - total data, $\mathrm{p}$ - significance.

in the dry season, with $\mathrm{p}<0.05$. The statistical analysis of the two variables (DIP \& SPM) shows that the role of DIP is more significant than SPM. The model equations resulting from Chl-a to DIP and the correlation coefficient ( $r$ ) at both locations and seasons are presented in Table 3.

The results of the research by Paudel et al. (2019) in micro-tidal estuaries in Texas are orthophosphates correlated with chlorophyll-a when TSS is less than $50 \mathrm{mg} \mathrm{L}^{-1}$. However, Balali et al. (2012) found no significant correlation between chlorophyll with phosphate $(\mathrm{y}=0.017 \mathrm{x}+1.519$ $\mathrm{R}^{2}=0.000, \mathrm{r}=0.005$, Log Chl a: PO4). The relationship of chlorophyll to the TP concentrations that can increase the prediction of algal biomass in lakes has been described by Smith (1982), Dillon (1983) and Jones (1993).

\section{The equation model from DIP to PIP}

Phosphorus is present in both dissolved and particulate forms in aquatic environments. The dissolved inorganic P (DIP) is preferentially utilized by living organisms. in estuary waters, approximately $20 \%$ of PP adsorbs the phosphate (DIP) (Jensen et al. 2006; Li et al. 2017). The use of a linear model can be used in describing the contribution of PIP to DIP. The results of the analysis of the linear model equation (Table 4). Table
4 shows that the relationship between DIP to PIP is linear. The Jepara coastal waters have a positive correlation in both seasons, while the Semarang coastal sea, has a negative correlation. The negative correlation illustrates that the $\mathrm{P}$ in suspension is released into waters into the dissolved phase (DIP). Phytoplankton will absorb P in the dissolved phase (DIP) through the process of photosynthesis and bloom rapidly. The biomass indicators of phytoplankton can be determined by the chlorophyll-a concentration (Colella et al. 2016).

Furthermore, the linear model between PIP and SPM can be seen in Table 5. The Jepara waters have a more linear model in the two seasons, compared to Semarang. Li, et al. (2017) found a similarity in the model of the relationship between PIP and SPM in the PRE, the South China Sea, which was different in each season and the model had a coefficient of determination $\left(\mathrm{R}^{2}\right)>0.56$.

\section{CONCLUSION}

The Semarang and Jepara Coastal Seas have an important role in regulating the dynamics of various species of $\mathrm{P}$, including dissolved inorganic phosphate (DIP) and inorganic phosphate particles (PIP) which greatly affects the concentration of chlorophyll-a. The results showed that the DIP

Table 4. Model equation of DIP and PIP in the rainy and dry season in Semarang and Jepara coastal waters

\begin{tabular}{|l|l|l|}
\hline \multicolumn{1}{|c|}{ Season } & \multicolumn{1}{|c|}{ Semarang } & \multicolumn{1}{|c|}{ Jepara } \\
\hline Rainy season & $\begin{array}{l}\text { DIP }=1.104-0.074(P I P) \\
\text { with value } R^{2}=0.492, p=0.187, n=4 \& r=-0.701\end{array}$ & $\begin{array}{l}\text { DIP =0.383+0.332(PIP) } \\
\text { with value } R^{2}=0.755, p=0.056, n=4 \& r=0.869\end{array}$ \\
\hline Dry season & $\begin{array}{l}\mathrm{DIP}=0.730-0.036(P I P) \text { with value } \mathrm{R}^{2}=0.265, \\
p=0.375, n=4 \& r=-0.515\end{array}$ & $\begin{array}{l}\text { DIP }=0.504+0.05(P I P) \\
\text { with value } R^{2}=0.267 p=0.373, n=4 \& r=0.516\end{array}$ \\
\hline
\end{tabular}

Note: $\mathrm{R}$ - coefficient of determination, $\mathrm{r}$ - coefficient of correlaiton, $\mathrm{n}$ - total data, $\mathrm{p}$ - significance.

Table 5. Model equation of SPM and PIP in the rainy and dry season in the Semarang and Jepara coastal waters

\begin{tabular}{|c|l|l|}
\hline Season & \multicolumn{1}{|c|}{ Semarang } & \multicolumn{1}{|c|}{ Jepara } \\
\hline Rainy season & $\begin{array}{l}\mathrm{PIP}=0.655+0.007(\mathrm{SPM}) \\
\text { with value } \mathrm{R}^{2}=0.251, \mathrm{p}=0.390, \mathrm{n}=4 \& \mathrm{r}=0.501\end{array}$ & $\begin{array}{l}\mathrm{PIP}=-2.154+0.046(\mathrm{SPM}) \\
\text { with value } \mathrm{R}^{2}=0.783, \mathrm{p}=0.046, \mathrm{n}=4 \& \mathrm{r}=0.885\end{array}$ \\
\hline Dry season & $\begin{array}{l}\mathrm{PIP}=1.769+0.029(\mathrm{SPM}) \\
\text { with value } \mathrm{R}^{2}=0.08, \mathrm{p}=0.977, \mathrm{n}=4 \& \mathrm{r}=-0.087\end{array}$ & $\begin{array}{l}\mathrm{PIP}=-2.128+0.092(\mathrm{SPM}) \\
\text { with value } \mathrm{R}^{2}=0.638, \mathrm{p}=0.105, \mathrm{n}=4 \& \mathrm{r}=0.799\end{array}$ \\
\hline
\end{tabular}

Note: $\mathrm{R}$ - coefficient of determination, $\mathrm{r}$ - coefficient of correlaiton, $\mathrm{n}-$ total data, $\mathrm{p}-$ significance. 
and PIP values of the Semarang and Jepara waters were $0.97 \mu \mathrm{M}$ (DIP), $1.61 \mu \mathrm{M}$ (PIP) and $0.50 \mu \mathrm{M}$ (DIP), $2.68 \mu \mathrm{M}$ (PIP) in the rainy season and 0.76 $\mu \mathrm{M}$ (DIP), $3.87 \mu \mathrm{M}$ (PIP) ) and $0.38 \mu \mathrm{M}$ (DIP), $3.53 \mu \mathrm{M}$ (PIP) in the dry season, respectively. The DIP concentration of the Semarang waters always shows a higher value in the rainy and dry seasons. In contrast, the concentration of phosphate inorganic particles (PIP) is always high in the dry season. The results of the linear model analysis between chlorophyll a to DIP and SPM showed the differences in location and season. The concentrations of DIP together with SPM affect the concentration of chlorophyll-a in both classes of water.

\section{Acknowledgments}

This research is part of a doctoral dissertation at Marine Science Program, Diponegoro University and funded with another APBN DPA SUKPA funded with grant number 16/UN7.5.10/PP/2019 Faculty of Fisheries and Marine Science, Diponegoro University, the budgeting year of 2019.

\section{REFERENCES}

1. Abell, J.M., Ozkundakci, D., Hamilton, D.P., Jones, J. R. 2012. Latitudinal variation in nutrient stoichiometry and chlorophyll-nutrient relationships in lakes: A global study. Fundam. Appl. Limnol. 181, 1-14.

2. Al-Enezi., E., B. Bockelmann-Evans, R. Falcone. 2016. Phosphorus adsorption/desorption processes of estuarine sediment: A case study - Loughor Estuary, UK. Arab J Geosci 9, 200. DOI 10.1007/ s12517-015-2014-1

3. Aspila, K.I., H. Agemian, \& A.S.Y. Chau. A semi-automated method for the determination of inorganic, organic and total phosphate in sediments. Analyst. 1976, 101, 187-197. DOI:10.1039/AN9760100187.

4. APHA. 1992. Standard Method for the Examination of Water and Wastewater. 18th edition. Washington, pp. 252.

5. Balali, S., S.A. Hoseini, R. Ghorbani \& H. Kordi. 2013. Relationships between Nutrients and Chlorophyll-a Concentration in the International Alma Gol Wetland, Iran. J Aquac Res Development, 4(3), 1-5. DOI: 10.4172/2155-9546.1000173

6. Colella, S., Falcini, F., Rinaldi, E., Sammartino, M., \& Santoler, R. 2016. Mediterranean Ocean Colour Chlorophyll Trends. PLoS ONE, 11(6), e0155756. https://doi.org/10.1371/journal.pone.0155756

7. Correll, D.L. 1998. The role of phosphorus in the eutrophication of receiving waters: A review. Journal of environmental quality, 27, 261-266.
8. Davidson, K., R.J. Gowen, P. J. Harrison, L.E. Fleming, P. Hoagland, G. Moschon. 2014. Anthropogenic nutrients and harmful algae in coastal waters. Journal of Environmental Management, 146, 206-216. doi.org/10.1016/j.jenvman.2014.07.002

9. Deborde, J., P. Anschutz, G. Chaillou, H. Etcheber, M. Commarieu, P. Lecroart, and G. Abril. 2007. The dynamics of phosphorus in turbid estuarine systems: Example of the Gironde estuary (France). Limnol. Oceanogr., 52(2), 2007, 862-872

10. Dillon P.J., Rigler F.H. (1974) The phosphorus-chlorophyll relationships in lakes. Limnol Oceanogr, 19, 767-773.

11. Dürr H.H., Laruelle G.G., van Kempen C.M., Slomp C.P., Meybeck M. and Middelkoop H. 2011. Worldwide Typology of Nearshore Coastal Systems: Defining the Estuarine Filter of River Inputs to the Oceans. Estuary. Coast., 34, 441-458.

12. Froelich P. 1988. Kinetic control of dissolved phosphate in natural rivers and estuaries: a primer on the phosphate buffer mechanism. Limnol.Oceanogr, 33(4), 649-668.

13. Jeffrey S.W. \& Humphrey G.F. 1975. New spectrophotometric equations for determining chlorophylls $\mathrm{a}, \mathrm{b}, \mathrm{c} 1$, and $\mathrm{c} 2$ in higher plants, algae and natural phytoplankton. Biochem Physiol, 167, 191-194.

14. Jensen H.S., Bendixen T. \& Andersen F.Ø. 2006. Transformation of particle-bound phosphorus at the land-sea interface in a Danish estuary. Water, Air, and Soil Pollution: Focus, 6, 547-555.

15. Jones J.R., Bachmann R.W. 1976. Prediction of Phosphorus and Chlorophyll Levels in Lakes. J Water Pollut Control Fed, 48, 2176-2182.

16. Labry C., A. Youenou, D. Delmas \& Michelon P. 2013. Addressing the measurement of particulate organic and inorganic phosphorus in estuarine and coastal waters. Continental Shelf Research, 60, 28-37.

17. Li, R., J. Xu, X. Li, Z. Shi \& P.J. Harrison. 2017. Spatiotemporal Variability in Phosphorus Species in the Pearl River Estuary: Influence of the River Discharge. Scientific Reports, 7(1364): 1-13. DOI:10.1038/s41598-017-13924-w.

18. Magumba, D., A. Maruyama, M. Takagaki, A. Kato and M. Kikuchi. 2013. Relationships between Chlorophyll-a, Phosphorus and Nitrogen as Fundamentals for Controlling Phytoplankton Biomass in Lakes. Environ. Control Biol., 51(4), 179185.

19. Maslukah, L., Wulandari, S.Y., Prasetyawan, I.B., \& Muslim. 2018. The Distributions Of N, P Nutrients and Its Relations with Chlorophyll-a: Case Study in Serang And Wiso Estuary, Jepara, Indonesia. Asian Jr. of Microbiol. Biotech. Env. Sc. 20(3), 123-129.

20. Maslukah, L., Zainuri, M., Wirasatriya, A., and Salma, U. 2019. Spatial Distribution of Chlorophyll-a and Its Relationship with Dissolved Inorganic Phosphate Influenced by Rivers in the North 
Coast of Java. Journal Ecological of Engineering, 20(7), 18-25.

21. Paudel, B., Montagna, P.A and Adams, L. 2019. The relationship between suspended solids and nutrients with variable hydrologic flow regimes. Regional Studies in Marine Science, 29, 1-9.

22. Sakamoto, M. 1966. Primary production by phytoplankton community in some Japanese lakes and its dependence on lake depth. Hydrobiologia, 62, 1-28.

23. Shabrina, B., Maslukah, L., and Wulandari, S.Y. 2018. Chlorophyll-a Distribution and Its Relation with Current Pattern in Northern Waters of Central Java. Omni-Akuatika, 14 (1), 69-76.

24. Siregar, V. \& A.F. Koropitan. 2016. Land-use change and its impact on marine primary production in Semarang Waters The 2nd International Symposium on LAPAN-IPB Satellite for Food Security and Environmental Monitoring. Procedia Environmental Sciences, 33, 520-531.

25. Smith, J., M.A., Burford, A.T. Revill, R.R., Haese, and J. Fortune. 2012. Effect of Nutrient Loading on Biogeochemical Processes in Tropical Tidal Creeks. Biogeochemistry, 108, 359-380.

26. Soliman, N.F, G.M. El-Zokm, M.A Okbah. 2017. Evaluation of phosphorus bioavailability in El Mex Bay and Lake Mariut sediments. International Journal of Sediment Research, 32, 432-441. DOI: 10.1016/j.ijsrc.2017.05.006

27. Søndergaard, M, S.E. Larsen, T.B. Jørgensen, E. Jeppesen. 2011. Using chlorophyll-a and cyanobacteria in the ecological classification of lakes.
Ecological Indicators 11, 1403-1412.

28. Subiyanto, S. 2017. Remote Sensing and Water Quality Indicators in the West Flood Canal Semarang City: Spatio-temporal Structures of Lansat-8 Derived Chlorophyll-a and Total Suspended Solids. IOP Conf. Series: Earth and Environmental Science, 98, 1-10.

29. Trommer, G., A. Leynaert, CE .C. Klein, A. Naegelen and B. Beker. 2013. Phytoplankton phosphorus limitation in a North Atlantic coastal ecosystem not predicted by the nutrient load. J. Plankton Res. (2013) 35(6): 1207-1219. First published online July 23, 2013 doi:10.1093/plankt/fbt070.

30. William, L., Marlon, K.W., Lewis, R. and Harrison, W.G. 2010. Multiscalarity of the nutrient-chlorophyll relationship in coastal phytoplankton. Estuaries and Coasts. 33, 440-447.

31. Wirasatriya, A., Prasetyawan, I. B., Triyono, C.D., Muslim, and Maslukah, L. (2018). Effect of ENSO on the Variability of SST and Chlorophyll-A in the Java Sea. IOP Conference Series: Earth and Environmental Science 116(1).

32. Yule, C.M., Boyero, L., and Marchant, R. 2010. Effects of Sediment Pollution on Food Webs in a Tropical River (Borneo, Indonesia). Mar. Freshwater Res. 61, 204-213.

33. Zhou, W., X. Yuan, A. Long, H. Huang \& W. Yue. 2014. Different hydrodynamic processes regulated on water quality (nutrients, dissolved oxygen, and phytoplankton biomass) in three contrasting water of Hong Kong. Environ Monit Assess. 186, 17051718. DOI 10.1007/s10661-013-3487-6. 